
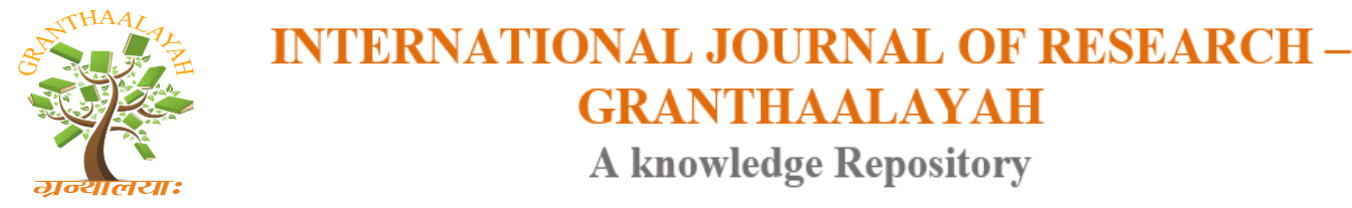

Management

\title{
ARTHASHASTRA V/S GRAHASHASTRA- A CRITICAL ANALYSIS OF GOLD MONETISATION SCHEME (GMS) IN INDIA
}

\author{
Dr. Ity Patni ${ }^{* 1}$, Dr. Somya Choubey ${ }^{2}$ \\ ${ }^{* 1}$ Assistant Professor, Manipal University, Jaipur, Rajasthan, INDIA \\ ${ }^{2}$ Assistant Professor, Raffles University, Neemrana, Rajasthan, INDIA
}

DOI: https://doi.org/10.29121/granthaalayah.v4.i11.2016.2418

\section{ABSTRACT}

Indian people treasure investment in Gold. The quantum of perceived value weighs more as emotional quotient is higher for this yellow metal. Families in India think that 'gold brings good fortune'. This inclination can be observed with the supporting fact that India has outshined itself as the largest gold consumer with 703 tons of gold jewelry in the year 2015. The summative demand of gold jewelry and investment has risen by $6 \%$ through which the demand has surged to 890 tons in this year (Shawn, 2016). Phenomenon for investment in gold in India and China is inelastic, despite of price fluctuations, populace continues gaze at gold.

Keywords:

Gold Monetisation Scheme, investment, gold consumer.

Cite This Article: Dr. Ity Patni, and Dr. Somya Choubey, "ARTHASHASTRA V/S GRAHASHASTRA- A CRITICAL ANALYSIS OF GOLD MONETISATION SCHEME (GMS) IN INDIA" International Journal of Research - Granthaalayah, Vol. 4, No. 11 (2016): 3743.

\section{INTRODUCTION}

Gold has been giving eternal elegant feeling to Indians as the major chunk is in the form of jewelry rather than bullion. The sentimental value has resulted in 20,000 tons of blocked gold in households and institutions which is not rotating in the economy. The value of gold held by Indians comprises nearly half of the country's GDP. This investment spree has been tagged with features such as highly liquid, precious and worthy, religiously significant, high ornamental value, value as heirloom, a safe haven, hedge against inflation and asset allocation etc (Kapoor, 2015). The returns on gold as against to other assets over the period of time is an evocative move in India as gold has outperformed in the previous decade. Moreover, the Indian gold loan market has expanded from 2002-2010 with a 40\% CAGR as it has higher loan to value ratio. A survey executed by Cognizant revealed that the Indian rural people count $65 \%$ of the total gold stock as they pledge gold to banks or NBFCs, if it is required in contingent times of crop failure, 
illness of family members, children's education, social and religious rituals etc. as cash can be raised in a short span of time and rate of interest on gold loan is lesser than rate on personal loan. It is well known that India has been facing the problem of Current Account Deficit (CAD) and almost half of our import bills are induced with demand of oil followed by gold. In the year 2015, gold imports bill were up by $12 \%$ which is near to US $\$ 35$ billion (Reuters, 2016). Therefore, Government of India (GOI) is trying effortlessly to curb the import for gold so that CAD could be narrowed to a great extent.

Referring to chart 1.1, in the year 2011 and 2012 gold imports of India were remarkably high with US\$ 53.92 billion and US\$ 52.76 billion respectively which was just US \$28.48 billion in the year 2010. The Current Account Deficit of 2011-12 and 2012-13 were $4.6 \%$ and $4.8 \%$ of GDP and on the other side the Trade Deficit stood at $10.2 \%$ and $10.8 \%$ of GDP in the respective years. Considering the fact that imports were $7.6 \%$ in $2005-06$ which touched to $12.6 \%$ in the year 2011-2012 (Prakash, 2013).

\section{INCREASED DEMAND}

$\begin{array}{lrr}\begin{array}{l}\text { GOLD IMPORTS } \\ \text { Month }\end{array} & \text { Tonnes } & \begin{array}{r}\text { Amount } \\ \text { (\$ million) }\end{array} \\ \text { Jan-15 } & 58.60 & \mathbf{1 , 5 7 2 . 4 0} \\ \text { Feb-15 } & 52.60 & \mathbf{1 , 9 8 1 . 6 1} \\ \text { Mar-15 } & 121.80 & \mathbf{4 , 9 8 4 . 8 6} \\ \text { Apr-15 } & 75.85 & 3,131.41 \\ \text { May-15 } & 60.81 & 2,421.25 \\ \text { Jun-15 } & 47.00 & \mathbf{1 , 9 6 8 . 0 3} \\ \text { Jul-15 } & 95.00 & 2,965.25 \\ \text { Aug-15 } & 113.60 & \mathbf{4 , 9 5 7 . 5 1} \\ \text { Sep-15 } & 52.50 & \mathbf{2 , 0 5 7 . 4 8} \\ \text { Oct-15 } & 41.60 & \mathbf{1 , 7 0 1 . 8 0} \\ \text { Nov-15 } & 98.00 & 3,539.92 \\ \text { Dec-15 } & 105.00 & \mathbf{3 , 7 0 0 . 0 0} \\ & 34,981.52\end{array}$

Market Realist $^{Q}$

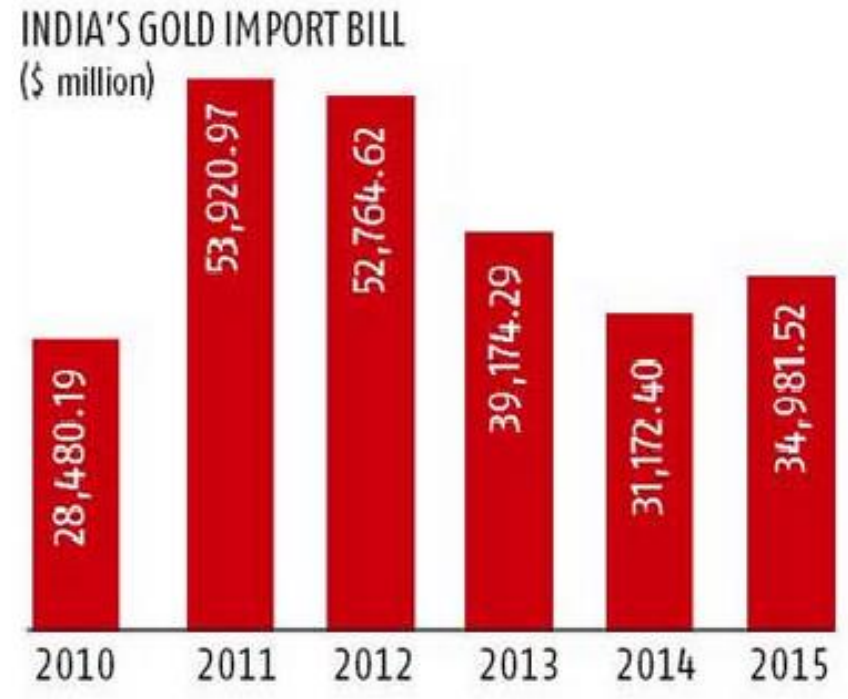

Source:www.busines-standard.com

Chart 1.1 Gold Import in Tons and India's Gold Import Bill

However, government took initiatives for curbing imports and promoting exports in the line of controlling trade and current account deficit as hiked import duty on gold step by step from $2 \%$ to $10 \%$ from January 2012 to August 2013 (Rao, 2015). The Central Bank of India knotted with 80:20 rule for exports of gold which induced that for every $100 \mathrm{Kg}$ of gold imported, $20 \mathrm{Kg}$ of gold has to be re-exported in any form. These measures rein the Current Account Deficit in the year 2013-14 (Refer Table 1.1). Though these steps lent hands in controlling import of gold but simultaneously the gold seized amount by customs were mounted (Refer Table 1.2). 


\begin{tabular}{|l|l|}
\hline Year & $\begin{array}{l}\text { Current Account } \\
\text { Deficit (\% of GDP) }\end{array}$ \\
\hline $2007-08$ & -1.3 \\
\hline $2008-09$ & -2.3 \\
\hline $2009-10$ & -2.8 \\
\hline $2010-11$ & -2.8 \\
\hline $2011-12$ & -4.2 \\
\hline $2012-13$ & -4.8 \\
\hline $2013-14$ & -1.4 \\
\hline $2014-15$ & -1.6 \\
(Till Quarter 2nd ) \\
\hline
\end{tabular}

Table 1.1: Current Account Deficit (As a \% of GDP)

(Source: Ministry of Commerce and Industry)

\begin{tabular}{|l|l|l|}
\hline Year & $\begin{array}{l}\text { Case } \\
\text { Reported }\end{array}$ & $\begin{array}{l}\text { Value of } \\
\text { Gold } \\
\text { Seized (Rs. } \\
\text { Crores) }\end{array}$ \\
\hline $2011-12$ & 503 & 43.87 \\
\hline $2012-13$ & 900 & 104.62 \\
\hline $2013-14$ & 2450 & 686.99 \\
\hline $\begin{array}{l}2014-15 \\
\text { (Up to } \\
\text { January) }\end{array}$ & 3412 & 931.55 \\
\hline
\end{tabular}

Table1.2: Smuggled Gold Seized by Custom

In the same line of effort for restraining the imports for Gold, Narendra Modi government introduced Gold Monetisation Scheme in November, 2015. The notion eyes for dampening physical demand for gold and to track the estimated 20,000 tonnes of gold which is lying idle with Indian households and institutions (Economic Times , 2015). In a country like China, recycling of gold is well-accepted by the people but in India it is not a practice to use old gold to buy new gold jewelry. Due to this, escalating demand of gold jewelry is being met with the import of gold. Gold Monetisation Scheme is a re-packaging of old Gold Deposit Scheme to entice the people of India.

\section{GOLD MONETIZATION SCHEMES- A BRIEF INTRODUCTION}

On $5^{\text {th }}$ November, 2015, Mr. Narendra Modi launched three gold related schemes in which one of them was named as Gold Monetization Scheme (GMS). The Gold Deposit Scheme was launched in 1999 by Government of India which was put into practice by banks. The guidelines were framed by Reserve Bank of India in which gold put in 1999 scheme will be allowed to run till maturity unless the depositor withdraws it prematurely. Keeping India's tradition and emotional attachment with the yellow metal Mr. Modi wants to fetch Governor of RBI's attention in his words, that there is a need to understand the difference between "Arthashastra (economicus) and Grahashastra (homoeconomicus), (Indian Express, 2015).

\section{STEPPING STONE KEYS OF GOLD MONETISATION SCHEME}

The limit of gold deposited into bank was earlier fixed as 500 grams in Gold Deposit Scheme which is now set at 30 grams in Gold Monetisation Scheme so that retail household come forward to unlock their deposits. For availing the benefits individual has to validate the purity at Collection and Purity Testing Centres (CPTC) which are the certified centres of Bureau of Indian Standards (BIS). The value of gold will be determined here and whatever are the interest notions are to be added in that particular time period. The recipient has to open a gold deposit account with commercial banks to park gold and then interest will be earned on them. That shall be payable either in the form of gold or cash as may be opted by the depositor which will be fixed at 
the time of opening of an account (Avabruth, 2015). For fetching the attention of investors, the earned interests are kept free from capital gain tax, wealth tax and income tax. The shortest tenure is of one year and banks will take care of 1-3 year deposits, 5-7 year medium term deposits and for long term deposits of 12-15 years banks will act on behalf of Government of India. The banks are allowed to sell and to let somebody borrow under GMS to MMTC to issue gold deposits to other banks or to jewelers who are also engaged in GMS. If there is a premature withdrawal that is subject to a minimum penalty and lock in period designed by individual banks. GMS-2015.PDF

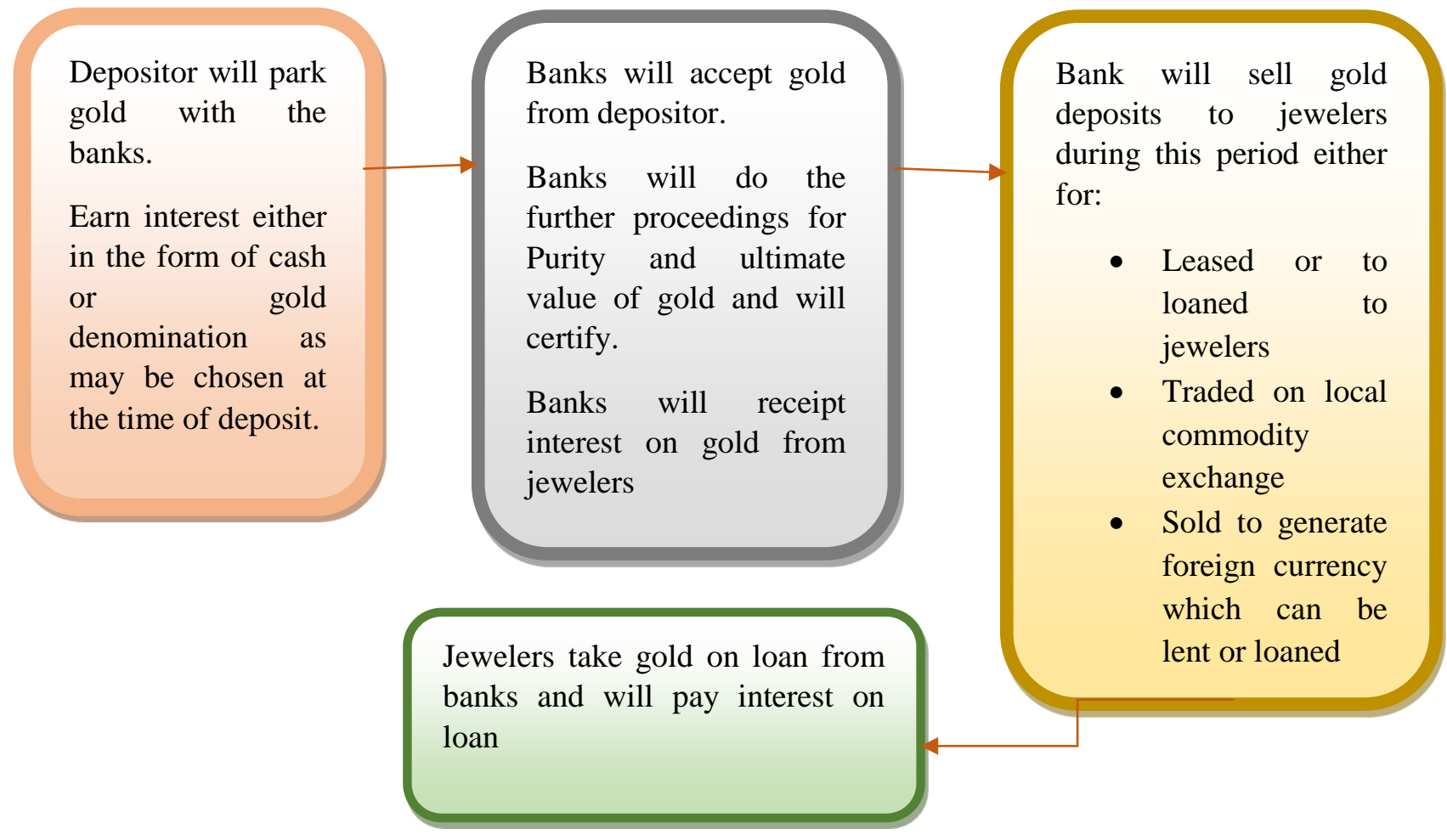

Chart 1.2: Gold Monetisation Scheme, 2015

\section{CONFLICT BETWEEN ECONOMICUS AND HOMOECONOMICUS (ARTHASHASTRA V/S GRAHASHASTRA)}

Arthashastra, The science of material gain is a rational approach which discusses the most practical kind. The Warren Buffet way for gold is tagged as. "It doesn't do anything but sit there and look at you." (Investopedia.com). Practically the economics says that investment in gold is idle investment if not employed effectively. The science of demand and supply states that if yellow fever temperature increases among the people, country has to place import orders which has direct bearing on the Balance of Payment situation for the economy. This has a standpoint image on inflation too as more import moreover, results in depreciation of currency because of more demand of dollars. It drains foreign reserves and pumps the import bills as India is the largest consumer of gold. Imperative aspect for gold as an investment blocks the capital. Since multiple centuries, Indians are allured with this glittering metal. The chunk of savings when dwells into gold it squeezes liquidity from the financial system. India's overall savings ratio is 
higher than other economies but the bitter fact is that it is in the form of physical savings. When any financial investment is done it results in the growth of an economy as money rotates among the system and there is an old saying 'money generates money'. For meticulous development or growth of an economy this must be an ideal phenomenon but the emotional attachment of Indians has limited it to lockers at home or conserved with religious institutes which does not generate any cash flow. Thus, it does not result in any pressing needs for individuals or for nation.

Eventually, Arthashastra says that eternal demand of gold is one of the central functions of economic prosperity, exchange rate, external stability, interest rate, inflation, import duty, easy availability of liquidity through gold loans etc. The reduction strategy of gold has varied parameters and real rate of return is always in a center.

'Homoeconomicus' adjective portrays human being as rational who has endless ability of making ideal decisions in all circumstances because of which individual keeps on utilizing the ability both for earning monetary and non-monetary gains. The individuals have their own view points as gold is the safest haven and a lucrative tool for hedging against inflation. The psychological view of Indians is inclined for their beloved jewelry as demanded gold from India is more in the form of jewelry than investment purposes. The wave length for common households with the Gold Monetisation Schemes does not match as people adore their jewelry like anything. Underneath are confronts which Gold Monetisation Schemes have to face from common households which slaps the Arthashastra:

Demand for gold will not dry in a very little while. India is a country which is having world's largest youth population with 356 million beating aside China's population who is having 269 million young people (ET Bureau, 2012). More than 50\% of the demand of gold is in the form of jewelry and every year around 10 million marriages takes place (Bajaj, 2013). As this figure is prospering, the near time demand with the fascinated metal is doubtful to be completely eliminated.

This is the appurtenance and corded with economic status among the society for individuals and shunning the symbolic wealth psychologically is a passive step for people of India.

The notion of melting the jewelry for keeping it in an electronic format will crush the buoyancy of this scheme as people invests their hard earned pennies in yellow metal and they would not be tempted with this ideology.

The gold investment as of now takes place without documentation and formal things. People will not take it positively to disclose their financials through the way of this scheme. Though the recently launched guidelines of RBI for KYC for gold deposit account is similar but people need to provide PAN card and other documents which terrifies them as it will come in front of the income tax officials eyes.

The interest rate facilitated by the Government of India is very low which is not even matching with the minimum bar of inflation. The effective interest is nominal which is not resulting in attraction of investors. It is not wise to expect that people will come forward for this scheme just to get a marginal benefit of $2 \%-3 \%$ in the form of interest. 
Moreover, the ornamental jewelry is generally studded with 22 carat of gold but the forms of bars are of 24 carat of gold. In India, 22 carat and 24 carat gold contains $91.6 \% 99.99 \%$ purity, which strikes to investor as overall value of money will reduce.

The scheme states that Bureau of Indian Standard's (BISs) own hallmarking centre will work for purity checking and further things which require huge infrastructure to be established across the country. Common man will not at all take pain to find the centre and spend the precious hours for the same which is not at all rational too to expect from people.

Though, economicus and homoeconomicus both support rational approach but human beings can never be rational all the time thus, they follow quasi-rational approach in their walk of life. This is also supported by the evolving field of 'Behavioral Finance' too.

\section{CONCLUSION}

This scheme is being executed from commercial banks of India. Banks are not finding it as red carrot as incentives are not lucrative. Initial draft of RBI was not giving any sweetener in the form of CRR/SLR requirement waiver for banks but the revised draft asserted that banks can count the mobilized gold under the general SLR requirements. As CRR is a tool for controlling inflation, technically it is not viable to allow banks to mobilize gold under CRR requirement. In and all, banks have to find this scheme in a tweaking manner because if cost of funds will not come down, banks will not tempt themselves for willingly participating in promoting this scheme. From business point of view, if depositor is earning interest there has to be a same amount of profitable deployment for banks too. RBI Issues Direction on Implementation of GMS, 2015.PDF.

If gold is deposited with bank it has to be returned to the depositor on maturity, if deposited gold loaned to a jeweler he too has to return it to bank, at the time of returning he has to buy it from market so in and all, import will not curb. The risk management practices by banks is a critical issue in GMS as banks will tender lucrative to consumers in the form of gold whereas jewelers will give cash to banks in the form of interest. If gold price raises speedily it may put banks in a drifty situation because banks simultaneously cannot increase interest rates and this might put banks into losses.

Indian economy's Arthashastra supports the notion for Gold Monetisation Scheme as it is a high time to control the demand of gold so that growth of economy will take a shape. The Grahashastra of Indian households asserts that it is quite passive to shun off the dear jewelry and to get it melted for earning just nominal amount of interest. However, if gold coins/bars are sheltered inactive in lockers or at home, consumer can rationally earn capital appreciation on idle gold. Government of India has targeted for 50 tons of gold in the launching year which amounts to approximately Rs.12,000 crore. As of now, individual's denomination is like showing a flickering flame to the sun but Indian temples have come forward for reserving yellow metal in this scheme still it is just a beginning.

On the whole, the idea of government is to bring down the materialistic demand for gold and for the same investor's education, awareness and financial literacy could play a promising role. The 
investment denomination for further demand can be enticed with gold related instruments in dematerialized form. As of now, Gold Monetisation Scheme is not attracting investors as government is hoping for 'Surajaya' in long run we too hope for rich hopes and aspirations through this scheme to take India to apex.

\section{REFERENCES}

[1] Avabruth, M. S. (2015). Gold Monetization Scheme. Economic and Political Weekly.

[2] Bajaj, S. (2013, July 28). A look inside India's billion dollar wedding industry. Retrieved from:

http://english.cntv.cn/:

http://english.cntv.cn/program/newsupdate/20130728/100890.shtml

[3] ET Bureau. (2012, November 18). India has world's largest youth population: UN report. Retrieved from:

http://articles.economictimes.indiatimes.com/:

http://articles.economictimes.indiatimes.com/2014-11-

18/news/56221890_1_demographic-dividend-youth-population-osotimehin

[4] ET Bureau. (2015, November 6). Prime Minister Narendra Modi launches three goldrelated schemes. Retrieved from:

http://articles.economictimes.indiatimes.com/:

http://articles.economictimes.indiatimes.com/2015-11-

06/news/68044018_1_somasundaram-pr-world-gold-council-gold-monetisation-scheme

[5] Indian Express. (2015, November 6). Modi launches three gold schemes. Retrieved from http://indianexpress.com/:

http://indianexpress.com/article/india/india-news-india/ahead-of-diwali-prime-ministernarendra-modi-launches-three-gold-schemes/

[6] Investopedia.com. (n.d.). Does Warren Buffett invest in gold? Why or why not? Retrieved from

http://www.investopedia.com:

http://www.investopedia.com/ask/answers/021615/does-warren-buffett-invest-gold-whyor-why-not.asp

[7] Kapoor, P. (2015). 7 reasons why Indians love gold. Retrieved from http://www.moneycontrol.com/:

http://www.moneycontrol.com/master_your_money/stocks_news_consumption.php?auton $o=696046$

[8] Prakash, P. (2013). Recent Trends in India's Current Account Deficit. Centre for Budget and Governance Accountability.

[9] Rao, D. K. (2015). Expansion in Import Basket vis-a-vis Increase in Exports. Ministry of Commerce and Industry, Department of Commerce.

[10] Reuters. (2016, January 18). Gold import bill up 12\%, reaches \$35bn in 2015. Retrieved from artofjewellery.com: http://artofjewellery.com/NewsMore.aspx?Id=60737

[11] Shawn, M. (2016, February 17). Demand for Gold Is on the Rise in China and India. Retrieved from http://marketrealist.com/: http://marketrealist.com/2016/02/chinapouncing-gold-amid-financial-stress/ 